\title{
MODERN DANGERS IN THE DEVELOPMENT OF THE RUSSIAN EDUCATION SYSTEM AND WAYS TO OVERCOME THEM: SOCIO-PHILOSOPHICAL ANALYSIS
}

\begin{abstract}
The article identifies and studies the features of the modern critical discourse of reforming the education system in Russia. Based on the socio-philosophical method of cognition, the authors of the article aim to identify and analyze some dangers in the modern education system of Russia that pose a threat to its full development, since they impede the training of highly qualified specialists and mature, responsible individuals. The article suggests measures to eliminate the identified dangers and generally optimize the innovative modern development of the education system. The authors of the article believe that the development of the education system should in practice become the most crucial priority of state policy so that the latter provides effective governing influence on the development of the educational space. This means that in the education system it is necessary to timely identify real and potential dangers, analyze them in detail and, accordingly, develop useful tools to eliminate these dangers and optimize the further safe development of the educational space. The education system in Russia will only then be able to train highly qualified specialists and mature, responsible individuals when it eliminates the dangers (deviations from safe development standards).
\end{abstract}

Keywords: critical discourse, education system, educational policy, modernization of education, social system, dangers, safe development of the educational space.

Introduction

The analysis of scientific and socio-philosophical literature shows that at present, there is still not enough research necessary to form a safe development of education. The problem of safe development of the modern Russian education system is widely studied in modern socio-philosophical literature, in particular, in the works of M. K. Gorshkov and F. E. Sherega (2010), B. S. Gershunsky (2001), N. V. Nalivaiko (2007, 2011, 2018), O. N. Smolin (2011), V. M. Filip- pov (2013), and others (Zalesny, Goncharov, \& Savchenko, 2019; Moros, 2013; 2014; Zalesny $\&$ Goncharov, 2019). However, at present, theoretical and methodological researches in the field of domestic education are not enough, thanks to which it would be possible to clearly define the ways of developing the education system based on the traditions of domestic education, and also taking into account the use of the best experience of foreign countries, which would prevent unreasonable options for reforming education. Based on this, the authors conclude that in the current 
conditions of development and transformation of Russian society, the need has ripened for sociophilosophical research of the educational system of Russia based on philosophical approaches to the analysis of the safe development of education. This became a determining factor in choosing the purpose of the research, which is to carry out a socio-philosophical analysis of the crisis of educational reforms and ways to ensure the safe development of the Russian education system.

\section{The Critical Discourse of Reforming the Education System in Russia}

Since the collapse of the USSR, various reforms and modernizations have constantly been taking place in the Russian education system. Moreover, the result of the implemented innovations, despite the correctness of the purposes and objectives declared by the Government of the Russian Federation, often does not meet the expectations of experts and civil society as a whole, since the level of quality of education in Russia is steadily declining. In the country, the critical discourse of reforming the national education system is gradually shifting from particular issues that cause bewilderment and fear for the future of Russian education to a systematic understanding of the existing problems in the modern educational space. In the critical fact is that the critical activity of the scientific and expert community is currently moving from private issues to complex and systemic problems of the Russian educational space. This indicates a radical change in the nature of the entire discourse. Criticism of the 1990s came down to the "struggle of progressive reformers" and the "conservative scientific and pedagogical community of the country" regarding the ways and mechanisms of development of the domestic education system, which, in essence, allowed the "progressive" reformers and authorities to ignore the "conservative-protective reaction" as outdated and ineffective in new realities position. Today, in the critical discourse of the sphere of education, there are more objective views, assessments, suggestions and recommendations are observed since subjective worldviews positions and personal preferences of authoritative specialists are becoming a thing of the past. In other words, the "quality of criticism" of the modernization process increases based on an in-depth and detailed analysis of failed reforms, while the analysis, nature and content of the argument differ in depth and consistency. Even the language of describing and explaining social reality becomes more objective, it uses concepts such as "red ribbons", "Goodhart's law", "Thomas's theorem", which provide conceptual instruments for understanding education as a particular social system. "Red ribbons" indicate boundaries beyond which an abundance of norms and procedures for regulating the system leads to its bureaucratization, reducing the development potential; Goodhart's law states that all indicators of social development, being the object of government control, lose their objectivity and lose trust, are often falsified and degraded; Thomas's theorem indicates that if a particular situation is perceived by people as real, it is real in its consequences. In other words, if the society in advance perceives the next reforms in the field of education as unsuccessful, then these reforms will indeed fail. Currently, a new strategy is being formed for an in-depth analysis of the current situation in the field of education and science. In their research, M. B. Sapunov and H. G. Thagapsoev (2018) come to the conclusion that the systemic interdisciplinary nature of the modern critical discourse of reforming the education system in Russia is based on the categories of 
meta-analysis, which makes it possible to form a culture of critical discourse as a fundamentally new space for professional communication ( $p$. 26).

In particular, in our opinion, the critical position of E. I. Trubnikova is interesting and convincing. She notes that the number of universities and their branches, dissertation councils, and defence of candidate and doctoral dissertations has significantly decreased in recent years. It was assumed that the purpose of institutional reforms would be to reduce the asymmetry in the Russian education system, as well as its integration into the international educational space and the level of quality in the field of science and education will increase. However, in practice, a completely different result is observed; therefore, it is seriously doubtful that according to the results of the "total struggle for quality", the forces interested in the development of the Russian education system won. Closed universities could also include those who strove for quality education, but were unable to meet the deliberately overstated regulatory requirements and suffered from the so-called "red ribbons". Among the potential applicants who did not enter could well be the future M. Lomonosov, D. Mendeleev, K. Tsiolkovsky, etc., ordinary scientists who did not overcome total bureaucratization and were disappointed in the chosen field of professional activity could also suffer. At present, it is impossible to be sure that regularly updated inflated requirements will not alienate talented people from the sphere of education and science and replace them with rent-oriented players (Trubnikova, 2018, p. 117). In current institutional conditions, the approaches and criteria for selecting applicants for funding can be recognized as adverse selection. In the educational system, the tendency of "scientific protectionism" and "subjectivity in assessing the activity" of researchers, teachers, educational and scientific organizations is intensifying (Gorin, 2017, p. 70).

Scientists V. S. Senashenko and A. A. Makarova rightly point out that higher education in modern Russia is becoming more and more internationalized every year. At the same time, the scientific and expert community is increasingly discussing the future of the country's education system. Many believe that the current difficulties in higher education are temporary and do not indicate that there are serious problems in the chosen path of development. At the same time, most researchers have a distorted view of the possibilities of their own education system inherited from the USSR. The question of what was constructive in the Soviet education system and what should be recognized as its shortcomings remains insufficiently studied. There is still a debatable question about the traditions of domestic education that need to be continued, and about the approaches that need to be abandoned in the process of modernizing the Russian education system (Senashenko \& Makarova, 2018, pp. 2442).

Ways to develop the system of domestic education based on international experience to resolve crisis phenomena began to be discussed in society and actively introduced in the 1980s. Subsequently, conditions were created for the corresponding transformation of the educational space in Russia. However, most of the reforms were carried out by trial and error. They did not have the necessary scientific justification, which led to negative results due to the directive mixing of different educational systems without preliminary modelling of the associated potential risks (Grebnev, 2018, pp. 5-18). The chosen strategy of the educational policy was entirely expected and naturally turned out to be destructive for the 
Russian education system, since educational systems of different values, structure and content were mixed (Senashenko \& Makarova, 2018; pp. 11-15; Moros, 2013). At the same time, at the beginning of 2010, it became apparent that the modernization of the educational system is destructive without deep analysis and awareness of the fundamental socio-cultural features of Russia, and the successful development of domestic educational institutions is merely impossible by simply mixing domestic and foreign experience (Senashenko \& Makarova, 2017, pp. 24-42).

In their critical analysis, researchers D. A. Sevostyanov and A. R. Gainanova believe that today the education system is created artificially, generating distortions of educational forms of different levels that distort Russian education. The new system is characterized by a lack of logic, a shift in the meanings of educational activity, and the appearance of inverse structures (Sevostyanov \& Gainanova, 2014, p. 45). It is the inversion that generates hybrids; a society with its basic institutions is currently "hybridized". In this regard, participants in public relations, following hybrid algorithms, enter into various relationships that, in fact, duplicate, overlap and replace rational structures in the formation of the Soviet period. However, society is accustomed to thinking about education within the framework of traditional stereotypes. Therefore it is genuinely unaware of the whole range of problems caused by the hybridization of all educational structures.

According to V. S. Senashenko and A. A. Makarova, a significant resource for correcting the results of modernization in the education system could be social engineering, which is a complex of methods, techniques and technologies for creating a genuinely sufficient educational space. In this case, we are talking about a large-scale so- cial experiment, in which specialists of the highest qualification throughout Russia should take part. An objective assessment of real problems and prospects for the development of the national educational space needs a long time, which will allow for a reassessment of values and a change in the course of educational policy (Senashenko \& Makarova, 2018, pp. 24-42).

S. V. Kamashev (2008) rightly notes that education connects the activities of citizens through their social environment, ensuring that people are prepared for the constant process of formation and development of a new generation with the functioning of the state. It is the state that is called upon to create the conditions necessary for the free development of the personality when its interests and needs can be fully satisfied. At the same time, the individual, being an element of complex social relationships, is called upon to preserve the integrity of society, to take part in upholding and strengthening its value system, and through its activities to help ensure its practical implementation (pp. 17-18).

Of course, as suggested by O. A. Belkov and L. G. Laptev, the education system functions in critical situations. However, it experiences the destructive impact of adverse circumstances associated with the emergence of certain dangers for the individual, society and the state (Laptev \& Belkov, 2011, pp. 17-23). In particular, in the context of financial and economic crises in the country, the demand for highly qualified specialists is rapidly falling, so it becomes difficult for graduates of universities to find work in their field of expertise, many go to work in those areas that bring more income, primarily in trade.

In their work, L. G. Laptev and O. A. Belkov (2011) draw attention to the fact that the medium for the formation of a person's personality and worldview is the middle and higher school, 
which develops the intellectual, labour and spiritual and moral social potential, so that society is capable of self-preservation and development (pp. 17-23).

In fact, in our opinion, the education system is an environment of actualization and mobilization of intellectual resources not only for national but also for global innovative development. In this regard, the implementation of the idea of a "breakthrough in the development of Russia", which was announced by the President of the Russian Federation in the annual message to the Federal Assembly of the Russian Federation in 2019 , is based primarily on the preservation, development and mobilization of Russia's intellectual potential in the framework of strengthening the system of domestic education. With this, we connect the possibility of the country's transition to an innovative path of development.

Thus, the critical discourse of reforming the education system in Russia from the time of the collapse of the USSR to the present has undergone dramatic changes. At the beginning of the XXI century, the scientific and expert community moved from active criticism of private innovations to a systematic approach in understanding the cause-and-effect relationships of the gradually degrading system of Russian education. The new methodological approach has made the criticism of each aspect of the educational process reform based on a comprehensive understanding of the integral development of the education system in its immanent dimensions. Today, this allows us to see a more significant "ontological and key" - a type of complexity and problem of Russian education in the general conditions of a changing Russia behind the individual shortcomings of educational policy and managerial technologies. The consequence of this phenomenon is the need for the development and practical ap- plication of new instruments for analysis and interpretation based on the principles of an interdisciplinary approach and ideas of modern social and humanitarian science. As a result of this, today, the critical discourse of modernization of the sphere of education is becoming more objective and scientific, able to determine the determinants of social pathologies in the educational space of Russia.

In the context of this research, we will call all the problems, challenges and threats in the system of Russian education a single term "danger", the ways to overcome which are of theoretical, methodological and practical interest. Consider the current dangers in the education system of Russia today.

\section{"Dangers" in the Modern System of Russian Education}

First of all, in our opinion, the danger of insufficiently competent management of the system of domestic education should be considered.

It should be noted that education management is a systematic activity. This is such a targeted effect on the object, as a result of which it acquires the required state. In relation to this, it is necessary to have a clear understanding of what is expected to get the state of the managed object, and therefore to present in detail the sequence of specific actions that will lead to the achievement of the purpose. In a situation where, due to the management of the education system, they are factually degrading, and severely destructive changes are taking place in it, this is not about management, but about destruction.

D. S. Volkova (2012) points out that the management of education is intended to be comprehensive and systematic, and not to be carried out by individual ill-conceived and isolated mea- 
sures (pp. 3-14). Education management should be based on a single, integrated, detailed strategy. However, in practice in Russia, as noted by A. A. Dorskaya (2012) it is rapidly deteriorating, as indicated by the high level of external and internal conflict, bureaucratization, corruption and other harmful factors in the system (p. 15). This leads to the accumulation and increase of problems in various areas of educational activity, including the quality and content of educational programs being developed and implemented, and staffing. In higher education, the most apparent destructive changes are taking place, even the very concept of "university" there is a lot of discussion. Among the main managerial dangers in the education system, specialists indicate the following: incompetence of authorities in the educational sphere; unreasonably large managerial staff throughout the country; irrational spending of budget funding; corruption; a constant increase in the reporting load; incorrect setting of purposes and objectives in the development of education; lack of scientific justification for reform programs (Pashentsev, 2013, pp. 130-133; Khromov, 2014, pp. 42-49).

In general, these dangers in the education management system are quite obvious; we believe that the latter danger should be clarified by the fact that reform is unreasonably frequent. In fact, the education system does not yet have time not only to adapt to innovations but also to comprehend them, as changes and additions to the recently revised specialized legislation reappear, which, in our opinion, significantly destabilizes the educational space and disperses the development guidelines, makes them incomprehensible to participants in the educational process and the general population.

Another serious danger is the blurring of boundaries in educational levels and the insuffi- ciently deep content of education. In particular, a serious concern of the scientific community is the fact that in fact, higher education in Russia has ceased to be professional. Currently, on average, two-thirds of all employers in the country (Kalachev, 2015, pp. 215-220) are ready to hire a university graduate without the experience of professional activity.

In 2017, the consulting company, "Boston Consulting Group", based on research conducted in Russia concluded that more than $80 \%$ of the working-age population of the country does not have the necessary competencies and skills to work in modern markets, and in Russia itself there is no necessary demand for knowledge. BCG specialists, using the methods developed by them, determined that citizens of the Russian Federation prefer to work as drivers (7.1\%), sellers $(6.8 \%)$ and security guards $(1.9 \%)$. At the same time, highly skilled labour, which belongs to the category of "knowledge" (solving creative and non-routine tasks, intellectual activity), is observed only in $17 \%$ of the population. This is 1.5 times less than in the United States or Japan, 1.7 times less than in Germany, 2 times lower than in Singapore and 2.6 times lower than the same indicator in the UK (Auzan, 2017).

Based on the data obtained, the experts concluded that the higher education system in Russia does not solve the problem. Obtaining university diplomas has become an empty social ritual, which only gives a certain general "pass" to society or provides a reprieve from the army. Education in Russia does not contribute to career advancement, does not lead to social success, the diploma has replaced education, and professionalism has turned into the ability to adapt and get a job. In this regard, 91\% of Russian employers believe that university graduates do not have the necessary practical skills, and $83 \%$ believe 
that the level of training of specialists in higher education is below average: in fact, they have to train graduates again on the job. The BCG report led to an active discussion in society (Auzan, 2017).

Today, universities do not train specialists of such a level that they are able to take even the lowest position in their field of professional training without experience. Graduates of universities, in particular, young teachers and doctors are not only challenging to get a job, but their salaries are meagre. In this regard, there is the socalled "brain drain" abroad. Moreover, people in the labour market are in demand, mainly without specialised professional knowledge, since work experience can compensate for gaps in education. We are talking about office managers, sales consultants, assistant managers, secretaries, couriers, security guards, insurance agents, network marketing agents, etc. Graduates of universities today in most cases do not go to work in their specialisation area, but, having received any higher education, they begin to work in positions where they can master the skills they need directly at the workplace. Unfortunately, the Russian education system today is focused primarily on the needs of the market, and not on the full development of the personality and high professionalism of future specialists (Moskovskaya, 2015, pp. 75-84).

We believe that the danger described above naturally leads to another danger associated with high-quality software for the educational process. In modern Russia, there is a constant emphasis on modernizing the education system, which in practice results in the introduction of out-oftouch innovations, the ideas of which are simply borrowed by the Ministry of Education and Science of the Russian Federation from the most developed countries of the world. These ideas are rapidly being introduced into the Russian legislation on education without taking into account the real needs, purposes, development purposes and capabilities of the domestic educational environment. As a result, there is a situation that is destructive for the country, when modernization in the education system is catching up with other countries, and this is not happening systematically, but in certain areas, the need for reform of which raises many doubts in the Russian scientific community. Moreover, in our opinion, modernization should not consist in catching up and reproducing the existing (current) specific level of an educational organization in other countries, but in mastering and introducing innovative mechanisms for the development of the individual, society and the state through the educational system as the crucial component of the system of ensuring national security. In this regard, one should act ahead of the curve, and not catch up with what is already in effect in others. Catching up and copying other people's models will never become a leader, will not implement their unique ideas, because they do not set such a goal and do not have mechanisms for its implementation.

Another danger is pedagogical methods in the education system. We noted above that the purpose and objectives of managing the development of the education system in Russia were initially defined and incorrectly formulated, and its constant reform does not have sufficient scientific theoretical and practical justification. In this regard, in the educational process, the selection of specific pedagogical methods from a wide range of possibilities is carried out arbitrarily and not systematically. Moreover, the developed criteria for evaluating the effectiveness of training using certain methods are based on the achievement of certain indicators of learning material in the educational potential that these methods 
have.

We believe that this approach is too narrow; it does not allow us to comprehend and control the effectiveness of the educational process in a complex. Not only does each teacher use a set of convenient methods at their discretion, but the methods themselves are focused primarily on the development of educational material, rather than educating the younger generation in Russian traditions.

In particular, the following pedagogical methods are currently widespread: information and communication, design, game, modular, healthsaving, integrative, differentiated, methods of critical thinking, problematic and developing learning, case study method and many others. Of course, each of these methods is useful, important and even necessary. However, the management of the educational realm proceeds not only in such a way that it does not provide a comprehensive analysis of the effectiveness of particular systems of methods at different levels of education and its conformity to the purposes and objectives of national education, but it does not ensure the continuity of the use of specific methods and their combination either.

In fact, in practice, there is a situation when a "fashion" is formed for specific pedagogical methods of teaching as the most modern and effective methods borrowed abroad. Then, for some time (1-3 years on average), teachers at all levels of the education system begin to emphasize their teaching methods on precisely these "relevant" methods within the framework of the next modernization, pushing other methods to the background, although they could have been more effective. Employees of the education system submit a lot of reports and regularly pass the certification. As part of this activity, they must convincingly demonstrate their ability to organ- ize an effective educational process, primarily based on pedagogical methods introduced into fashion. It seems that such a policy of choosing pedagogical methods in the Russian education system at all levels is destructive and poses a threat to national security.

In general, numerous expert researches are devoted to the analysis of the degree of effectiveness of the implementation of modern state policy in the field of education, which are presented for extensive discussion in the framework of various scientific measures to study the mutual influence of national security phenomena and the education system. In this context, it is worth paying attention to the fact that it is universities (institutions of the education system) that become the platforms for lively discussions of scientists about the cause-effect relationships of modern challenges and threats to Russia's national security and the search for optimal solutions to pressing problems in the field of education.

In particular, one of the frequently discussed problems of the modern education system is the apparent inequality of universities located in different regions. It is well known that students aspire to Moscow and St. Petersburg to receive the so-called elite education, as well as the fact that the level of quality of technical equipment of capital's universities is significantly higher than this indicator in remote poor regions, which every year exacerbates the risk of social inequality in society and the destruction of the regional education system. In this regard, the research of T. A. Kovaleva, M. A. Safonova and M. M. Sokolov (2017, pp. 63-79) is interesting. These scientists have shown that it is easier for universities in the wealthiest regions to earn money (however, if we are not talking about Moscow or St. Petersburg, it is more difficult for them to attract the best stu- 
dents), but they have to make more effort to maintain the loyalty of the teaching staff. At the same time, capital's universities have the best laboratories, but it is easier for the provincial universities to achieve high rates of the average salary in the region and use scores. In this regard, we can conclude that the working conditions of universities in different regions of the country are so differentiated that it is currently impossible to evaluate their work according to general criteria. This threatens the principle of unity in the development of educational space in Russia.

In the domestic education system, there is also such a danger as a failure of the relationship between educational levels, characterized, in particular, by the degradation of school education during parallel experiments in the innovative development of secondary vocational and higher education (Sharipova \& Permyakova, 2016, pp. 80-81), as well as other no less surprising contradictions. The danger of this phenomenon lies in the imbalance of all levels of the education system and undermining the foundation of the educational space in Russia as such

In connection with the foregoing, it can be concluded that the education system is able to fully form a personality and prepare a professional only in the most optimal safe conditions, while deviations from them create various dangers. In this article, we have identified and analyzed only the main hazards, which include the following: illiterate management of the education system; blurring of boundaries in educational levels and insufficient content of training; low quality of educational process software and innovations that are divorced from real life; unmotivated, non-systematic use of pedagogical methods; inequality of Metropolitan and regional universities; failure of the relationship between levels of education.
The national security system, in our opinion, is designed to identify all real and potential dangers and find the most optimal ways to eliminate them, based on the existing mechanism of mutual conditioning and interconnection with the education system described above. It is necessary to create instruments to control and manage the development of the Russian education system in a safe direction for the individual, society and the state.

$$
\begin{gathered}
\text { Ways to Eliminate "Dangers" in } \\
\text { the Education System }
\end{gathered}
$$

We believe that the identified and analyzed dangers in the Russian education system that prevent the full formation of the personality of Russian citizens and their professional development can be eliminated by solving the following tasks:

1) rejection of the idea that education is a service designed to make a profit since in reality education is the most critical function of the state, based on investing in the future development of the country and ensuring its preservation and gaining leading positions in the world;

2) multiple reductions in the reporting of education system employees, associated with the need to justify the existence of rapidly increasing staff of officials at various levels;

3) the rationalization of the expenditure of budgetary funds, the exclusion of financing from budgetary funds of non-core specialities in universities. Instead, comprehensive support should be provided for priority areas and specialities in higher education for the development of the national economy. It is also essential to develop a support system for qualified teachers, the most capable and 
active students and graduate students;

4) the rejection of the destructive and humiliating dependence of universities on the number of students studying on a fee basis. It is necessary to exclude the occurrence of a situation where the leadership of a higher educational institution holds onto each contract student and does not expel those who do not have the desire and ability to study. Timely objective expulsion of lagging students helps maintain a high level of quality education in the regions and the country as a whole;

5) a targeted policy to counter the continually increasing bureaucratization of the education system. In this direction, it is essential to increase the requirements for officials responsible for the development of the Russian educational space, as well as to immediately dismiss those who in practice have shown their incompetence or been involved in corruption scandals and connections;

6) to reform the system of domestic education solely based on competent expert opinion of the scientific and pedagogical community, and not be guided by voluntarism and the desire for experiments on the part of officials;

7) to restore the systemic relationship between higher education and the "national economy" so that higher education does not deal primarily with social education, adaptation and socialization, but solves the specific tasks of training highly qualified personnel in demand in the national economy;

8) the main areas of work that will help to ensure a breakthrough in the development of the country through the education system should be the following: financing of education and science systems; construction of new and support for existing research centres; assistance to young scientists; the introduction of proven management and marketing methods of work in state enterprises, attracting the potential of the media to enhance the prestige of the professions of a designer, scientist, engineer, etc. (Lutsenko, 2013, pp. 58-60; Zalesny \& Goncharov, 2020).

As a social institution with activities focused on meeting the needs of society, education is necessary to ensure self-preservation and full development of society. The national security system should ensure a situation where education will not only be comprehensive, sustainable and effective but will also be able to improve optimally in order to be able to adapt promptly to the constantly changing conditions of the external and internal environment in the context of globalization. The evolution of the educational process is designed to be systemic, consistent and large-scale. In this regard, school teachers, university professors, scientists and politicians need to introduce such innovations into the theory and practice of education that will ensure high-quality preparation of all students for an active life for the good of their country.

\section{Innovative Development of the Education \\ System in the Context of the Need to Ensure National Security}

We believe that a comprehensive discussion of systemic educational innovations, the search for opportunities to eliminate existing restrictions in their application and improve the quality of education should be priority areas of broad public discussion, primarily in expert circles. It is important to define the concept of educational innovations, assess the current state of their im- 
plementation in the Russian education system, and identify potential mechanisms for improving the domestic educational space based on innovations (so-called "growth points" in this area).

Innovation can be directed at progress in one, as well as simultaneously at several or all aspects of the educational system: theory and practice, curricula, teaching, policy, technology, institutions and administration, institutional culture and pedagogy. They can manifest themselves in everything that has a positive impact on the learning process and students. Educational innovations affect all stakeholders: the student, parents, teachers, scientists and politicians, demanding their active participation and support (Yudina, 2014, pp. 49-50)

Officials when planning any innovations must prepare scientifically-based answers to several questions: "Why are they needed?", "How will they work?", "What will be the result?", "Are innovations necessary?", "What needs of a society satisfy specific innovations?". The answers to these questions will allow us to assess the degree of compliance of the proposed innovations with the goals and objectives of the development of the education system and, accordingly, determine whether they are constructive and useful for Russia or will be destructive. Useful innovations are the norm, destructive ones are not the norm, since they contradict the condition of safe formation and development of the individual in the educational space, and, therefore, pose a threat to society and the state.

As an example of useful and safe innovations, we can cite a lot of foreign educational programs that should be used more often in Russia and actively create and implement their analogues. For example, there is a program "Thiel Fellowship" Peter Lill, who suggests that people implement their own projects instead of sitting in the classroom. According to the author of the program, a college or university can be useful in finding out what has been done before, but it will not help to do something new. Each of the participants in this program develops its individual development course (project). Peter Lill suggests that in order to succeed, one should think more about himself/herself instead of competing in outdated areas of professional activity. The program offers the implementation of a personal idea instead of performing mandatory tests, equals the ability to take on significant risks, not considerable debts. How exactly to spend two years of training in the program depends on the person himself, it only helps to meet the right people. The most challenging thing for young entrepreneurs is that they have not yet met everyone they need to know in order for the business to develop correctly and efficiently. Peter Lill's "Thiel Fellowship" program helps people meet investors, partners, and potential clients in Silicon Valley and beyond $^{1}$ (Miller, 2012; Hempel, 2016).

The distance learning program "Learning how to learn" is also available on coursera.com. This course provides free access to new teaching methods used by specialists in the field of art, music, literature, mathematics, science, sports and many other sciences. People will learn how the brain uses two very different learning modes and how it processes and summarizes information. The program allows understanding previous misconceptions about learning, methods of memory, combating procrastination, and useful best educational practices allow more efficient assi-

1 Information from the official website of the Thiel Fellowship program by Peter Lily. (2020). THIELFELLOWSHIP. Retrieved June 27, 2020, from: http://thielfellowship.org.

2 Learning How to Learn: Powerful Mental Tools to Help You Master Tough Subjects. COURSERA. Retrieved June 27, 2020, from: https://ru.coursera.org/learn/learning-how-to-learn\#. 
milation of new information and speedier knowledge acquisition in complex subjects. Using the author's approaches, regardless of the level of students' knowledge, one can change their thinking and, eventually, their whole life. In addition to this program, there is a special course "Mdshift" for those who plan to make a career.

In our opinion, modern, safe Russian education through the introduction of useful innovative approaches should reorient from the average mass training of graduates with their subsequent training at universities to develop the professional potential of the young generation and ensure its relevance in the domestic labour market. In this, in our opinion, the need for innovations in the field of education is manifested, while the need for them is due to the corresponding request of society itself and the state.

We believe that we can only partially agree with the position.

Dwelling on modern innovative achievements of Russia in the international arena in the field of education, M. A. Polozikhina, in particular, cites the following statistics, "In 2018, the Russian team took second place at the $59^{\text {th }}$ International Mathematical Olympiad for high school students (Cluj, Romania) among 116 teams from all over the world, the country won three gold and one silver medal in $29^{\text {th }}$ International Biological Olympiad (Tehran, Iran). In 2017, 10 Russian universities were included in the group of 500 best universities in the world in the field of "Physical Sciences" according to the weekly magazine Times Higher Education (THE), MSU and NSU topped the ranking of universities in the British company Quacquarelli Symonds (QS) for developing countries in Europe and Central Asia. In 2017, Russia won the first place in the team event of the Worldskills World Championship in professional excellence among 77 coun- tries of the world (1300 participants). Of the 52 competencies, Russian participants received gold medals in six professions, silver - in four more (mainly related to programming and trading) and one bronze (for stone carving)" (Polozhikhina, 2018, pp. 18-20).

It seems that the tangible achievements listed by M. A. Polozhikhina on the world arena in the field of education in the long term do not contribute to the prolific development of the educational space. In our view, the state should strive not just for high achievements among developing countries and victories in international Olympiads, but, above all, for leadership in shaping trends in the field of education, including the announcement and holding of its own international competitions. They can be organized first in the space of the Eurasian Economic Union (by analogy, for example, with "tank biathlon"), and then gradually expand the geography of participants. It is vital to create Russian international educational platforms, to which students from all over the world could join, similar to those that we examined above. In other words, the development of the educational system, as well as ensuring national security, should not be catching up, but ahead of the character. Whereas in solving military-strategic issues of ensuring national security, Russia has already managed to develop and introduce technologies that have no analogues in the world today, but in the field of education, the country cannot yet reach such a level. However, leadership in the field of education and science for Russia, in our opinion, is no less important than the possession of the most modern types of weapons.

\section{Conclusion}

Thus, we note that education is a resource 
for strengthening the foundation of the future "technological breakthrough" in Russia in the context of modernization and ensuring the general well-being of the nation and country. In this regard, in our opinion, the development of the education system should, in practice, become the most crucial priority of state policy.

1. The real and potential dangers must be timely identified in the education system, analyzed in detail and, accordingly, developed effective tools to eliminate such dangers and optimize the further safe development of the educational space. The education system in Russia will only then be able to train highly qualified specialists and mature, responsible individuals when it does not have in itself dangers (deviations from safe development standards).

2. The current trend towards objectification of the critical discourse of the consequences of constant reform of the education system will provide a comprehensive scientific approach to understanding and explaining to society the national values of the Russian education system, as well as develop and implement effective approaches, methods with the means of its full development in the interests of the state and its citizens.

\section{REFERENCES}

Auzan, A. A. (2017). Shchitaem sebya velikimi, a ekonomiku imeem 3\% ot mirovoy (We Consider Ourselves Great, and We Have 3\% of the World Economy, in Russian). Vogazeta.ru. Retrieved July 15, 2020 from: https://vogazeta.ru/articles/2018/2/15/economics/2035-schitaemsebyavelikimi_a ekonomikuimeem 3 ot mirovoy.
Dorskaya, A. A. (2012). Formirovanie innovatsionnogo prostranstva Rossii i uchastie $v$ nem universitetov: pravovoe izmerenie (The Formation of the Innovation Space of Russia and the Participation of Universities in it: The Legal Dimension, in Russian). Law and Education, 10, 9-22.

Gorin, S. G. (2017). Zarplaty prepodavatelei vuzov, granty $i$ nauchnye protektsionizm (Salaries of University Teachers, Grants and Scientific Protectionism, in Russian). Universal education in Russia, 6(213), 68-75.

Grebnev, L. S. (2018). Nyneshnii raund Bolonskogo protsessa: Rossiya i ne tol'ko... (po rabotam V. I. Baydenko i N. A. Seleznovoi) (The Current Round of the Bologna Process: Russia and Not Only ... (Based on the Works of V. I. Baidenko and N. A. Selezneva), in Russian). Universal Education in Russia, 1(219), 5-18.

Hempel, J. (2016). Inside Peter Thiel's Genius Factory. Retrieved July 15, 2020 from: https://www.wired.com/2016/12/inside -peter-thiels-genius-factory.

Kalachev, V. Yu. (2015). Sistemnye problemy podgotovki kadrov v Rossii: vypuskniki $i$ rabotodateli (Systemic Problems of Training in Russia: Graduates and Employers, in Russian). Bulletin of the Adygeya State Unviersity. Series 5: Economics, 4(170), 215-220.

Kamashev, C. V. (2008). Natsional'naya bezopasnost' i obrazovanie Rossii (National Security and Education of Russia, in Russian). Bulletin of the Kemerovo State University of Culture and Arts, 3, 17-19. 
Khromov, S. A. (2014). O metodicheskikh trebovaniyakh $k$ novomu pokoleniyu uchebnoi literatury (On the Methodological Requirements for a New Generation of Educational Literature, in Russian). Education and Science: Questions of Theory and Practice, 1, 42-49.

Kovaleva, T. A., Safonova, M. A., \& Sokolov M. M. (2017). Chto opredelyayet stoimost' obucheniya $v$ rossiiskikh VUZakh? (What Determines the Cost of Studying at Russian Universities?, in Russian). University Management: Practice and Analysis, 1, 63-79.

Laptev, L. G., \& Belkov, O. A. (2011). Obrazovanie $i$ natsional'naya bezopasnost' (Education and National Security, in Russian). Bulletin of the Moscow University. Series 14. Psychology, 4, 17-23.

Lutsenko, N. O. (2013). "Utechka Mozgov": tendentsii i mery po preodoleniyu (Brain Drain: Trends and Measures to Overcome, in Russian). Power, 8, 58-60.

Miller, C. C. (2012). Drop Out, Start Up. Nytimes.com. Retrieved July 15, 2020 from: https://www.nytimes.com/2012/07/20/education/edlife/the-thiel-fellowship-aids-young-entrepreneurs-withgrants.html.

Moros, E. F. (2013). Cennosti i celi sovremennoi modeli obrazovaniya (Values and Goals of the Modern Model of Education, in Russian). Modern Research on Social Problems, 2(14), 87-96.

Moros, E. F. (2014). Sistema obrazovaniya kak faktor obespecheniya global'noi bezopasnosti (The Education System as a Factor in Ensuring Global Security, in Russian). Philosophy of Education, 5(56), 24-36.
Moskovskaya, A. A. (2015). Dolzhno li Vysshee obrazovanie sootvetstvovat' sprosu na rynke truda? (Should Higher Education Meet Demand in the Labor Market?, in Russian). Higher Education in Russia, 10, 75-84.

Pashentsev, D. A. (2013). Upravlenie sistemoi vysshego obrazovaniya: sovremennye problemy (Management of the System of Higher Education: Modern Problems, in Russian). Law and Education, 9, 130-133.

Polozhikhina, M. A. (2018). Sistema obrazovaniya $v$ Rossii s tochki zreniya formirovaniya chelovecheskogo kapitala (The Education System in Russia from the Point of View of the Formation of Human Capital, in Russian). ESPR, 2, 1820.

Sapunov, M. B., \& Thagapsoev, Kh. G. (2018). Kul'tura kriticheskogo diskursa o vysshem obrazovanii $i$ nauke (po stranitsam zhurnala) (The Culture of Critical Discourse on Higher Education and Science (through the Pages of the Journal), in Russian). Universal Education in Russia, 7, 20-27.

Senashenko, V. S., \& Makarova, A. A. (2017). Obrazovatel'naya gibridizatsiya kak instrument modernizatsii sistemy vysshego obrazovaniya (Educational Hybridization as a Tool for the Modernization of the Higher Education System, in Russian). Alma Mater (Bulletin of the Higher School), 1, 11-15.

Senashenko, V. S., \& Makarova, A. A. (2018). Obrazovatel'nye gibridy v vysshem obrazovanii Rossii (Educational Hybrids in Higher Education in Russia, in Russian). Universal Education in Russia, 
8/9, 24-42.

Sevostyanov, D. A. \& A. R. Gainanova, A. R. (2014). Tsennosti obrazovaniya: inversiya smyslov (Values of Education: Inversion of Meanings, in Russian). Universal Education in Russia, 2, 43-47.

Sharipova, N. A., \& Permyakova, I. S. (2016). Problemy obrazovaniya $v$ Rossii (Problems of Education in Russia, in Russian). Siberian Trade and Economic Journal, 4(25), 80-81.

Trubnikova, Ye. I. (2018). "Krasnye lenty" v sfere nauki i obrazovaniya ("Red Ribbons" in the Field of Science and Education, in Russian). Universal Education in Russia, 1, 108-121.

Volkova, D. S. (2012). Mesto i rol' obrazovatel'nykh uchrezhdeniy $v$ sovremennoi Rossii (The Place and Role of Educational Institutions in Modern Russia, in Russian). Bulletin of the International Institute of Informatization and Public
Administration Named after P. A. Stolypin, 1, 3-14.

Yudina, T. A. (2014). Sistema menedzhmenta kachestva - innovatsionnye tekhnologii (Quality Management System - Innovative Technologies, in Russian). Higher Education in Russia, 9, 49-50.

Zalesny, J. \& Goncharov, V. (2019). Ontological Core of the Social Concept of Global Constitutionalism: A Socio-Philosophical Analysis of Content and Evolution. Future Human Image, 12, 129-142.

Zalesny, J. \& Goncharov, V. (2020). View of the Social Concept of Global Constitutionalism on the Legal System. Journal of Legal, Ethical and Regulatory Issues, 23(2), 1-6.

Zalesny, J., Goncharov, V. \& Savchenko, M. (2019). Model of the Evolution of Social Development in the Philosophy of Global Constitutionalism. Wisdom, 13(2), 51-61. 